Ruhl, P. J., K. F. Kellner, J. M. Pierce, J. K. Riegel, R. K. Swihart, M. R. Saunders, and J. B. Dunning, Jr. 2018. Characterization of Worm-eating Warbler (Helmitheros vermivorum) breeding habitat at the landscape level and nest scale. Avian Conservation and Ecology 13(1):11. https://doi. org/10.5751/ACE-01185-130111

Copyright (C) 2018 by the author(s). Published here under license by the Resilience Alliance.

Research Paper

\title{
Characterization of Worm-eating Warbler (Helmitheros vermivorum) breeding habitat at the landscape level and nest scale
}

Patrick J. Ruhl ${ }^{1}$, Kenneth F. Kellner ${ }^{1,2}$, Jameson M. Pierce ${ }^{1}$, Jeffrey K. Riegel ${ }^{1}$, Robert K. Swihart ${ }^{1}$, Mike R. Saunders ${ }^{1}$ and John B. Dunning, Jr. ${ }^{1}$

${ }^{1}$ Forestry and Natural Resources Department, Purdue University, ${ }^{2}$ West Virginia University

ABSTRACT. The Worm-eating Warbler (Helmitheros vermivorum) is typically described as a mature forest species requiring moderate to steep slopes and dense understory vegetation for breeding. However, nesting microhabitat characteristics vary regionally. Given the extensive variation in landscape topography, forest composition, and habitat structure across the breeding range, identification of important local landscape features and microhabitat characteristics is needed to formulate and implement improved conservation actions for the species. We characterized important habitat associations at two distinct scales (the landscape scale and the nest scale) to provide a detailed description of Worm-eating Warbler breeding habitat requirements in southern Indiana. Results from our point count and nest searching surveys emphasize the importance of terrain variables (i.e., steep SW-facing slopes) within mature forest habitat in southern Indiana. In addition, the structural microhabitat variable, leaf-litter depth, was an important predictor at the nest scale. Our dual-scale characterization of important habitat associations during the nesting portion of the breeding season provides a more complete understanding of Worm-eating Warbler breeding ecology in this portion of its range.

\section{Caractérisation de l'habitat de nidification de la Paruline vermivore (Helmitheros vermivorum) aux échelles du paysage et du nid}

RÉSUMÉ. On décrit habituellement la Paruline vermivore (Helmitheros vermivorum) comme une espèce de forêt mature qui recherche un terrain en pente modérée à abrupte et un sous-étage végétal dense pour y nicher. Toutefois, les caractéristiques du microhabitat de nidification varient régionalement. Étant donné les grandes différences de topographie du paysage, de composition forestière et de structure de l'habitat dans l'aire de reproduction, il faut identifier les éléments locaux importants du paysage et les caractéristiques du microhabitat pour qu'on puisse définir et mettre en oeuvre de meilleures activités de conservation pour l'espèce. Nous avons caractérisé les principales relations entre la Paruline vermivore et son habitat à deux échelles distinctes (celle du paysage et celle du nid) afin de décrire de façon détaillée ses besoins en matière d'habitat de nidification dans le sud de l'Indiana. Les résultats de nos dénombrements par points d'écoute et de nos recherches de nids soulignent l'importance des variables du terrain (c.-à-d. pentes abruptes exposées au sud-ouest) en forêt mature dans le sud de l'Indiana. De plus, une variable structurale du microhabitat, soit l'épaisseur de la litière, s'est avérée explicative à l'échelle du nid. La caractérisation des associations importantes avec l'habitat que nous avons faite à deux échelles durant l'étape de nidification en saison de reproduction permet une compréhension plus complète de l'écologie de nidification de la Paruline vermivore dans cette partie de son aire.

Key Words: aspect; breeding; conservation; nest; passerine; slope; territory

\section{INTRODUCTION}

For decades, habitat loss and fragmentation have had a negative impact on the abundance and reproductive success of birds that breed in the forests of the eastern United States (Robbins et al. 1989a, Robinson et al. 1995, Bender et al. 1998, Sauer et al. 2017). Therefore, improved conservation of the remaining contiguous forested habitat is critical for maintenance of the North American breeding bird community. Sound management of wildlife habitat for conservation relies on knowledge of the biological and ecological factors that affect the survival of species. Several studies have described habitat requirements and environmental variables associated with breeding bird density or nesting success (Gale et al. 1997, Howell et al. 2000, Smith et al. 2008).
Relationships between habitat characteristics and breeding density may not offer insights on fitness consequences (Van Horne 1983), but a basic understanding of habitat associations is an important first step for conservation.

The Worm-eating Warbler (Helmitheros vermivorum) is a forest bird, which is considered a species of conservation concern by the U.S. Fish and Wildlife Service (USFWS 2008), and is prioritized as such on several individual state lists (e.g., Indiana, Illinois, Wisconsin, New Jersey). In addition, the Worm-eating Warbler is listed as a priority species by private conservation initiatives, such as Partners in Flight (Rosenberg et al. 2016). Described as a forest interior species, the Worm-eating Warbler is vulnerable to extensive landscape fragmentation (Donovan and Flather 
2002, Keller and Yahner 2007). Thus, most management plans for the species recommend conservation of large tracts of contiguous forest, though there is also a clear benefit to some level of habitat heterogeneity (i.e., provision of early successional habitat within a matrix of mature forest) for various stages of Worm-eating Warbler life history (Wallendorf et al. 2007, Bakermans et al. 2012, Ruhl et al. 2018)

Across the geographic extent of its breeding range, encompassing most of the southeastern United States from Louisiana to Massachusetts, nesting microhabitat characteristics of the Wormeating Warbler vary regionally (Vitz et al. 2013). For example, the importance of slope and canopy cover differs throughout the breeding range (Vitz et al. 2013). Furthermore, forest tree species composition varies substantially from largely oak-hickory (Quercus-Carya) or beech-maple (Fagus-Acer) stands in the Central Hardwood Region (Wenny et al. 1993) to loblolly pine (Pinus taeda) plantations in North Carolina (Watts and Wilson 2005). Because Worm-eating Warblers require large forest tracts for breeding (Hayden et al. 1985, Robbins et al. 1989b) and experience extensive regional variation in habitat use patterns including landscape topography, forest composition, and habitat structure, identification of important landscape and microhabitat attributes is needed to target more effective conservation actions for the species throughout its breeding range.

In addition to geographic differences, Worm-eating Warbler habitat preferences change throughout the breeding season. Worm-eating Warbler is known to prefer mature forest habitat for nesting and utilize early successional habitat during the postfledging period (Vitz and Rodewald 2006, 2011, Burke et al. 2017, Ruhl et al. 2018). Furthermore, the importance of habitat characteristics and structural attributes may differ among the mate-pairing, nest-building, egg-laying, and incubation stages of the nesting period, depending on the scale of the landscape associated with each stage (Levin 1992, Turner 2001). For example, proximity to a nearby forest stream may affect the efficiency of nest construction if the availability of wet leaves and other preferred nesting materials (e.g., sporophyte stems of Polytrichum spp.) are a limiting factor (Vitz et al. 2013). Similarly, structural characteristics, such as the presence of dense understory vegetation, thick leaf-litter layer, or steep slope at the nest site, could be important variables influencing nest success (Vitz et al. 2013). Previous research has described a preference of Worm-eating Warblers to forage in chestnut oaks during the early breeding season (Greenberg 1987). Thus, tree species composition in the nesting area could potentially influence foraging efficiency during the nestling stage. Conservation recommendations for Worm-eating Warbler and other mature forest species should reflect the distinct habitat associations of the nesting and postfledging periods, and their associated implications for survival and recruitment at multiple spatial scales (King et al. 2006, Vitz and Rodewald 2006, Streby and Andersen 2011).

Worm-eating Warbler breeding habitat has previously been characterized using point count surveys, spot mapping, or nest searching (Wenny et al. 1993, Gale et al. 1997, Watts and Wilson 2005). However, most descriptions of Worm-eating Warbler breeding and nesting habitat are qualitative in nature, and the few studies that report quantitative data only focus on habitat associations relevant to a single scale and method (i.e., only point counts, only spot mapping, only reproductive success). In this study, we used quantitative methods to describe Worm-eating Warbler breeding habitat in southern Indiana at two distinct spatial scales (landscape and nest), using two techniques (point counts and nest searches). We predicted that important breeding habitat characteristics for Worm-eating Warbler would be scale dependent. More specifically, we predicted that landscape-level features associated with mature forest habitat and topographic heterogeneity (e.g., canopy height and slope) would influence breeding density, and microhabitat features, such as understory vegetation density and leaf-litter depth, would influence nest placement. By considering two distinct spatial scales within the nesting portion of the breeding season, we provide a more complete understanding of the species' breeding ecology in this portion of its breeding range, which is a necessary first step for a complete characterization of regional habitat requirements for the species.

\section{METHODS}

\section{Study location}

This research was conducted at nine sites (78-110 ha in size) located within the Morgan-Monroe (39 $19^{\prime} 12.4^{\prime \prime} \mathrm{N}, 86^{\circ} 26^{\prime} 55^{\prime \prime}$ W) and Yellowwood ( $\left.39^{\circ} 7^{\prime} 40.8^{\prime \prime} \mathrm{N}, 86^{\circ} 19^{\prime} 57^{\prime \prime} \mathrm{W}\right)$ state forests in southern Indiana, USA. The two state forests together comprise $>19,000$ ha, and the average stand age is 87 and 91 years old (at Yellowwood and Morgan Monroe state forests, respectively). The overstory is dominated by oak (Quercus spp.), hickory (Carya spp.), and tulip poplar (Liriodendron tulipifera), and the understory is dominated by sugar maple (Acer saccharum) and American beech (Fagus grandifolia). Basal area range from 21.7-29.9 $\mathrm{m}^{2} / \mathrm{ha}$, and tree densities range from $923-1527$ trees/ha (Saunders and Arseneault 2013). Our research sites were established as part of the hardwood ecosystem experiment (HEE), a 100-year study of forest ecosystem responses to forest management in state forests (Kalb and Mycroft 2013).

\section{Point count surveys}

At a broad scale, we used point counts and a combination of forest inventory, high-resolution GIS, and light detection and ranging (LiDAR) data to model Worm-eating Warbler breeding density as a function of habitat variables across the landscape. Between May 20 and June 20 in 2012 and 2014, we conducted point counts at 99 points across the 9 research sites $(9-13$ points per site). Sampled points were a subset of bird survey points established as part of a larger study (Kalb and Mycroft 2013) in which points were placed systematically at a spacing of $150 \mathrm{~m}$ to cover the entire area of each site. To obtain our final subset of points, we excluded points that were in recently harvested areas as well as points without a nearby forest inventory plot. All points in the final set were separated by $\geq 150 \mathrm{~m}$. We recognize that this spacing is closer than the $250 \mathrm{~m}$ typically recommended for point count surveys (Ralph et al. 1995, Matsuoka et al. 2014). However, we are confident that adjacent points were adequately independent for several reasons. First, the dataset of bird observations was truncated to only those observations within 75 $\mathrm{m}$ of each plot center to ensure there was no overlap in sample area between adjacent points. Second, adjacent points were sampled in quick succession temporally, minimizing the number of birds traveling between points. Finally, observers were trained to exclude birds known to have been recorded already at an adjacent point. 
Points were sampled twice each year between 0600 and 1100 EDT. On each sampling occasion, a single observer recorded all visual and auditory detections of birds within $100 \mathrm{~m}$ of the point. Time of observation, distance (estimated visually to nearest $10 \mathrm{~m}$ ), and sex (if possible) were recorded for each detection of a Wormeating Warbler. After the observation data were collected, we truncated the dataset to include only observations made within $75 \mathrm{~m}$ of the plot center to ensure there was no overlap in sampled areas between adjacent point counts.

Habitat data were collected for each point location from several sources. Mean maximum canopy height in the 75 -m radius area around each point was derived from a 3-m resolution raster of canopy height, obtained via airborne LiDAR collected in 2009-2011 (IndianaMap, http://www.indianamap.org; Barnes et al. 2016). Understory stem density for each point was obtained from forestry inventory data. Forest inventory plots were part of a concurrent study at the same sites (Saunders and Arseneault 2013). All bird points included in the study had a forest inventory plot located randomly within a $75 \mathrm{~m}$ radius of the bird point. Within each 0.005 -ha inventory plot, we estimated understory density as the number of woody stems with $<5 \mathrm{~cm}$ diameter at breast height (i.e., $1.35 \mathrm{~m}$ height).

Using a $1.5-\mathrm{m}$ resolution digital elevation model (DEM) of the study area (IndianaMap, http://www.indianamap.org), we calculated mean elevation (m), aspect (degrees), and slope (degrees) in a 75-m radius around each point using the $\mathrm{R}$ package Raster (Hijmans et al. 2017). Aspect was transformed from degrees to Beers' aspect, which ranges from zero (southwesternfacing slopes) to two (northeastern-facing slopes; Beers et al. 1966).

\section{Nest searching}

At a fine scale, we analyzed the specific microhabitat preferences of 23 female Worm-eating Warblers between a $2.5-10 \mathrm{~m}$ radius around each nest. We conducted opportunistic nest searches for Worm-eating Warbler within all nine of the HEE research sites from May 16 to June 30, 2016-2017. We located nests using behavioral cues of adults (e.g., carrying food, territorial singing, or aggressive chipping). Once a nest was located, we recorded the location using waypoint averaging with a handheld Garmin eTrex 20 GPS (Garmin International, Olathe, Kansas, USA). After nesting activity had subsided, we returned to the nest locations to collect microhabitat data. To compare nest sites with a paired random point, we selected a point $50 \mathrm{~m}$ away from each nest site in a random direction. We collected the same set of microhabitat data at nest sites and random points.

At each nest location or paired random location, we established 4 sampling plots located $2.5 \mathrm{~m}$ away in each cardinal direction. At each plot, we measured leaf-litter depth, understory vegetation density, and canopy cover. Leaf-litter depth down to the duff layer was measured with a ruler. We estimated understory vegetation density using a profile board method modified from MacArthur and MacArthur (1961) and described in Peterson et al. (2015). The profile board $(2.0 \mathrm{~m} \times 0.25 \mathrm{~m})$ was divided into eight $0.25 \mathrm{~m}$ $\mathrm{x} 0.25 \mathrm{~m}$ alternating black and white squares. One researcher held the profile board, oriented vertically, in one of the four sampling plots and an observer stood in the opposite sampling plot. We estimated (rounded to $10 \%$ ) the amount of area obscured by vegetation within each of the eight squares (Peterson et al. 2015). We estimated percent canopy cover by taking a photograph of the canopy with a SONY DSC-S650 digital camera (SONY Corporation, Minato, Tokyo, Japan) positioned $2 \mathrm{~m}$ above the ground, facing north. We used ImageJ software (Rasband 1997-2016) to separate color channels, convert each photograph to a binary image, and calculate the ratio of black pixels as an estimate of percent canopy cover (Peterson et al. 2015). Measurements of litter depth, understory vegetation density, and canopy cover were averaged across the four sampling plots to obtain mean values for each location. For each location, we also calculated mean maximum canopy height and mean Beers' aspect within a 10-m buffer using the DEM and LiDAR-derived canopy height raster. Finally, we used a clinometer to measure percent slope at the location.

\section{Data analysis}

\section{Point counts}

We fit a single-visit $N$-mixture model to the point count data (Amundson et al. 2014). For the abundance submodel, abundance at each point was modeled as a Poisson random variable with canopy height, understory density, elevation, slope, and aspect as covariates. As we were interested specifically in the effects of these habitat covariates on abundance, we fit a single model containing the main effects and did not compare among alternative models. Tests of model goodness-of-fit indicated a Poisson error structure was appropriate for the count data. Both visits to each sample point in a given year were included in the analysis; to account for this serial and spatial dependence of visits, we included random effects of both site and sample point in the abundance model. The detection probability submodel was separated into 2 components: (1) probability of availability (i.e., whether or not the bird was visible or singing during the count) and (2) probability of detection by an observer, given that the bird was available to be detected (Amundson et al. 2014). Overall detection probability was the product of these two components. Probability of availability was estimated using a time-removal model (Farnsworth et al. 2002), with ordinal date included as a covariate. Probability of detection was estimated using a distance-sampling approach (Farnsworth et al. 2005) with wind speed (Beaufort scale) and a random observer effect included as covariates. All continuous covariates were standardized to a $Z$-score prior to analysis.

The $N$-mixture model was fit in a Bayesian framework using JAGS (Plummer 2003) called from within R (R Development Core Team 2016) using package jagsUI (Kellner 2015). We ran three Markov chain Monte Carlo (MCMC) chains each with 70,000 total iterations, a burn-in of 60,000 iterations, and a thinning rate of 100 . We considered the model to have adequately converged when the Brooks-Gelman-Rubin statistic for all parameters was $<1.1$ (Brooks and Gelman 1998). A covariate effect was considered to have a significant effect on abundance or detection when the estimated $95 \%$ credible interval around the parameter estimate did not overlap zero.

Recently, some concerns have emerged over identifiability of parameters in $N$-mixture models like the one we fit (Barker et al. 2017). To make sure that our inference was not impacted, we also fit a Poisson generalized linear mixed model (using package lme4 
in R) to our count data that was identical except that the detection component was omitted. The results we obtained from the general linear mixed models (GLMM), in terms of covariate effects, were essentially identical to the $N$-mixture model (Appendix 1, Table A1.1). Hence, subsequent results and discussion focus solely on the $N$-mixture models.

\section{Nest searching}

We used a multivariate analysis of variance (MANOVA) in program R (R Development Core Team 2016) to test whether site type (nest or random point), year, or the interaction between these two variables influenced Worm-eating Warbler nesting microhabitat. We used Welch's paired sample $t$-tests in program $\mathrm{R}$ to test for differences in maximum canopy height, percent slope, Beers' aspect, leaf-litter depth, percent canopy cover, and understory vegetation density between nest sites and random sites. Unless otherwise defined, all reported values represent means \pm SE.

\section{RESULTS}

\section{Point counts}

Overall, we had 259 Worm-eating Warbler detections across the 2 years of point counts. Mean estimated detection probability was 0.53 . We found no significant effect of either ordinal date or wind speed on detection probability (Table 1). Mean estimated abundance based on the model was 0.75 males/ha. Slope had a significant positive relationship with Worm-eating Warbler abundance, with a one-standard deviation increase in slope (equivalent to an increase of 3.07 degrees) corresponding to a $20 \%$ increase in estimated abundance. Aspect had a negative effect on abundance, with a one-standard deviation increase (a shift of 0.57 Beer's aspect units from SW to NE) corresponding to a $15 \%$ decrease in abundance (Table 1). Estimated abundance at the lowest observed slope ( 3.7 degrees) was 0.43 males/ha, whereas on the steepest slope (19.6 degrees) estimated abundance was 1.09 males/ha. On perfectly northeastern-facing slopes, estimated abundance was 0.49 males/ha, whereas estimated abundance on southwestern-facing slopes was 0.85 males/ha. Elevation, canopy height, and understory density had no significant effect on Wormeating Warbler abundance, although there was a positive trend for the latter two (Table 1).

\section{Nest searching}

We located 23 nests, 8 in 2016 and 15 in 2017. The MANOVA indicated a significant multivariate effect of site type contributing to differences in microhabitat (Wilks' $\lambda=0.57, F_{6.37}=4.59, P<$ 0.01 ), but no effect of year (Wilks' $\lambda=0.82, F_{6,37}=1.35, P=0.26$ ) or the interaction between site type and year (Wilks' $\lambda=0.77$, $\left.F_{6,37}=1.87, P=0.11\right)$. Individual $t$-tests revealed no difference in mean maximum canopy height $\left(t_{47.7}=0.98, P=0.33\right)$, mean Beers' aspect $\left(\mathrm{t}_{44.0}=-0.90, P=0.37\right)$, mean percent canopy cover $\left(t_{41.1}=-0.45, P=0.66\right)$, or mean understory vegetation density $\left(t_{43.9}=0.97, P=0.34\right)$ between nest sites and random points. However, mean slope $\left(t_{43.9}=4.68, P<0.001\right)$ and mean leaf-litter depth $\left(\mathrm{t}_{44.0}=2.4, P<0.01\right)$ were significantly greater (averaging $44 \%$ and $18 \%$ higher, respectively) at nest sites than random sites (Table 2). Although Beers' aspect was not statistically different between nest sites and random sites, 12 of the 23 nests were located on SW-facing slopes, and only 3-4 nests were located on each of the 3 remaining slopes (NE, NW, and SE; Fig. 1).
Table 1. Output from the N-mixture model for Worm-eating Warblers (Helmitheros vermivorum). Estimates of covariates with effects we considered significant (the $95 \%$ credible interval did not overlap zero) are marked with an asterisk. SD = standard deviation.

\begin{tabular}{lcc}
\hline \hline Parameter & Estimate & $95 \%$ Credible Interval \\
\hline Availability Model & & \\
Intercept & 0.11 & $(-0.12,0.31)$ \\
Ordinal Date & -0.17 & $(-0.39,0.05)$ \\
& & \\
Detection Model & & \\
Intercept & 42.49 & $(29.38,63.71)$ \\
Observer SD & 0.42 & $(0.18,0.94)$ \\
Wind & -0.08 & $(-0.17,0.02)$ \\
& & \\
Abundance Model & & \\
Intercept & 0.28 & $(0.01,0.55)$ \\
Site SD & 0.13 & $(0.00,0.44)$ \\
Point SD & 0.08 & $(0.01,0.22)$ \\
Canopy Height & 0.07 & $(-0.10,0.23)$ \\
Understory Density & 0.06 & $(-0.08,0.20)$ \\
Elevation & 0.06 & $(-0.13,0.25)$ \\
Slope & $0.18^{*}$ & $(0.03,0.33)$ \\
Aspect & $-0.16^{*}$ & $(-0.34,-0.01)$ \\
\hline
\end{tabular}

Table 2. Beers' aspect, slope, canopy height, leaf-litter depth, percent canopy cover, and understory vegetation density values at Worm-eating Warbler (Helmitheros vermivorum) nest sites and random points in southern Indiana in 2015-2017 (mean \pm standard error). Asterisks indicates a significant difference in means $(\mathrm{P} \leq 0.05)$.

\begin{tabular}{lcc}
\hline \hline Habitat Variable & Nest Site & Random Point \\
\hline Aspect & $0.66( \pm 0.15)$ & $0.85( \pm 0.15)$ \\
Slope & $* 64.09( \pm 4.39)$ & $* 35.61( \pm 4.20)$ \\
Canopy Height & $25.27( \pm 0.94)$ & $23.85( \pm 1.11)$ \\
Leaf-Litter Depth & $* 4.20( \pm 0.22)$ & $* 3.45( \pm 0.22)$ \\
\% Canopy Cover & $0.81( \pm 0.01)$ & $0.81( \pm 0.01)$ \\
Understory Vegetation & $13.79( \pm 1.92)$ & $11.09( \pm 2.01)$ \\
\hline
\end{tabular}

\section{DISCUSSION}

In this study, we identified terrain variables (e.g., slope and aspect) as significant predictors of Worm-eating Warbler breeding habitat use at both spatial scales. In addition, we identified leaflitter depth as an important microhabitat characteristic at the nest-site scale. Although we observed a positive trend with respect to mature forest habitat structure metrics in the landscape-level analysis, variables such as maximum canopy height, canopy cover, and understory vegetation density were not significant predictors at either of the two spatial scales. Given the described life history of the species (Vitz et al. 2013), as well as the available breeding records for Indiana (Castrale et al. 1998, Brock 2006), it is clear that Worm-eating Warbler is restricted to largely forested landscapes within the state. However, our results also emphasize the importance of steep SW-facing slopes for breeding habitat selection within mature forest in Indiana. 
Fig. 1. Total number of Worm-eating Warbler (Helmitheros vermivorum) nests located on NE [0-90], SE [90-180], SW [180-270], and NW [270-360] facing slopes during the 2016 and 2017 breeding seasons in southern Indiana.

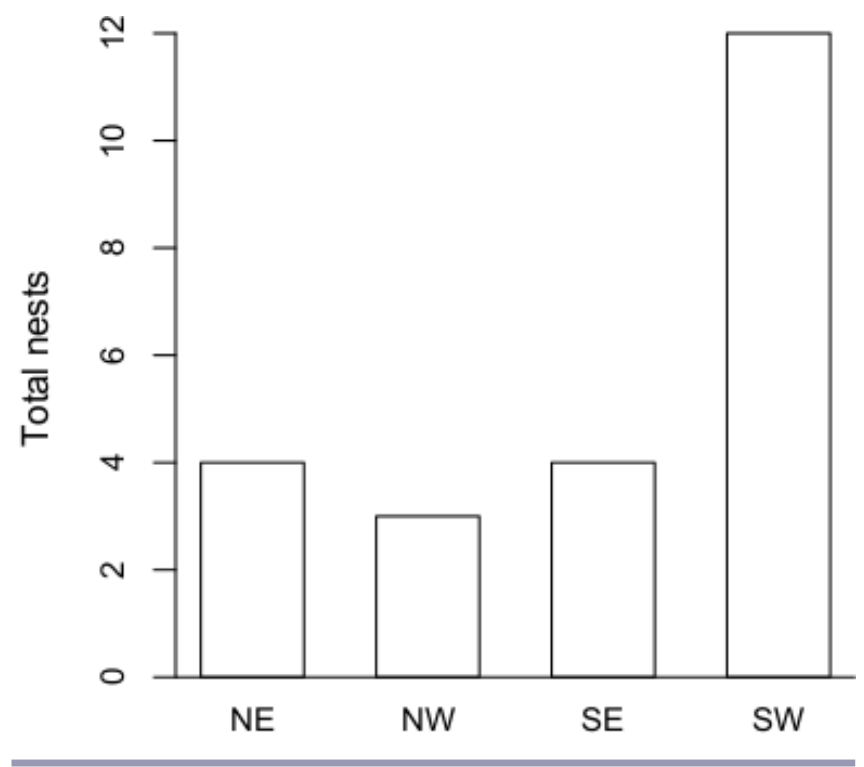

Throughout various stages of the nesting period of the breeding season (i.e., mate pairing, nest building, egg laying, incubation, nestling provision), Worm-eating Warblers use the forest ecosystem in multiple ways. Thus, multiscale characterization of important habitat features using multiple techniques is necessary to fully understand the complexity of this system (Levin 1992). Males occupy reliable singing perches within a delineated territory early in the breeding season, and females seek out suitable habitat for nest sites within these territories. Our study identified the importance of leaf-litter depth for female nest site selection. However, males may also influence nest locations if other factors, such as tree species composition (e.g., the predominance of oak species within a given area; Greenberg 1987), have an impact on Worm-eating Warbler territory delineation.

Although there are some known exceptions in the flatter portion of the breeding range (e.g., North Carolina; Watts and Wilson 2005), Worm-eating Warbler is generally associated with moderate to steep slopes for nesting (Vitz et al. 2013). As expected, in our study, slope was a significant predictor of abundance at the broad landscape scale (Table 1) and was also significantly greater at nest sites than at random points at the fine scale (Table 2). At the population level, Worm-eating Warbler is not declining as rapidly as some other mature forest species across its breeding range (e.g., Cerulean Warbler or Wood Thrush; Rosenberg et al. 2016). However, Worm-eating Warbler is listed as a species of special conservation concern in the state of Indiana and would therefore benefit from conservation efforts specifically directed at providing ample and adequate habitat (i.e., sites on steep, SWfacing slopes with well-developed leaf litter) availability during the nesting portion of the breeding season.

In Indiana, there are currently no logging restrictions based on percent slope, other than the physical and safety limitations of logging equipment. However, if slopes are too steep to accommodate mechanical harvesters, timber can be harvested with a chainsaw and cable-skidded out with a tractor. Thus, the physical attributes of Worm-eating Warbler nesting habitat alone do not render them de facto protected, because steep slopes in our region do not pose significant logistical constraints to forestry operations. Our results, which demonstrate the significance of steep slopes for Worm-eating Warbler breeding habitat at two distinct spatial scales, highlight the importance of terrain considerations when managing forest habitat for the species.

The role of aspect on breeding density and nest site selection in our study was unexpected. Southwest-facing slopes were a significant predictor of Worm-eating Warbler breeding density in our point count models (Table 1). In addition, at the nest scale, we located 12 nests on SW-facing slopes as opposed to 4 on NEfacing slopes ( $n=23$; Fig. 1$)$. The association of Worm-eating Warbler nest sites with SW-facing slopes has not been previously described. Based on the variation in habitat (e.g., tree species composition and topographic heterogeneity) across its extensive breeding range (Vitz et al. 2013), it is reasonable to suspect that the factors driving the observed association of Worm-eating Warbler with SW-facing slopes may also vary regionally.

The specific factors driving the association of Worm-eating Warbler with SW-facing slopes are unclear. The structural makeup of leaf litter could differ on NE- and SW-facing slopes in our study system based on differences between mesophytic and xeric tree species composition and the associated leaf-litter characteristics (Crosby and Loomis 1974, Schwilk and Caprio 2011, Kreye et al. 2013), potentially providing better nesting material for Worm-eating Warblers on SW-facing slopes. Leaves from xeric tree species (e.g., oaks) provide a drier, more loosely compacted litter layer than mesophytic tree species (e.g., maples; Crosby and Loomis 1974). This difference in litter composition could influence the nesting appeal for ground-nesting species such as Worm-eating Warbler. In addition, during the nesting portion of the breeding season in Maryland, $80 \%$ of Worm-eating Warbler foraging efforts were directed toward leaf gleaning in chestnut oak (Quercus montana; Greenberg 1987). Thus, it is possible that foraging preference (i.e., selecting sites with a prevalence of xeric oak species), rather than nesting microhabitat on the forest floor, may be driving the association of Worm-eating Warbler nest sites with SW-facing slopes. There may also be a thermoregulatory benefit for a ground-nesting warbler species to orient the nest toward the southwest if slightly higher ambient temperatures throughout the day can provide an evolutionarily advantageous trade-off with respect to time spent brooding on the nest or foraging away from the eggs (Conway and Martin 2000).

Because there is no precedent in the literature for the association of breeding Worm-eating Warblers with SW-facing slopes, it is also important for us to consider potential caveats with this association within an ecological framework. Understory biomass and plant diversity are known to be higher on mesic NE-facing slopes in comparison to xeric SW-facing slopes (Olivero and Hix 1998). Along with steep slopes and contiguous mature forest, dense understory vegetation is a commonly described characteristic feature of Worm-eating Warbler breeding and nesting habitat (Rodewald and Smith 1998, Vitz et al. 2013). In 
our study, understory vegetation was not a significant predictor of Worm-eating Warbler breeding habitat at either the broad scale or the fine scale. In fact, most Worm-eating Warbler nests occurred on slopes with a relatively open understory. Although we did not preferentially select SW-facing slopes during opportunistic nest searches, Peterson et al. (2015) demonstrated the inherent bias associated with traditional nest searching techniques. Thus, it is possible that nest-searching efforts were more successful along SW-facing slopes due to lower understory vegetation density. In addition, we did not monitor nesting success in this study, therefore it is possible that nests on SW-facing slopes may have reduced nest success. Future research involving more detailed nest observations is needed to fully elucidate this association with SW-facing slopes. Likewise, researchers should be cautious when using the abundance or density of breeding males within a given habitat type to ascribe a value to breeding or nesting grounds (Van Horne 1983). Depending on the breeding ecology of an organism, a low breeding density may actually reflect territorial exclusion of high quality breeding habitat by a few high-quality males (Van Horne 1983). However, we observed a positive association between $\mathrm{SW}$-facing slopes and breeding site usage at two distinct ecological scales and emphasize the need for more research to more fully understand this association.

Previous research has demonstrated the importance of large sections of intact mature forest to fulfill Worm-eating Warbler breeding habitat requirements (Vitz et al. 2013), but specific estimates of minimum area requirements vary drastically among studies (21-340 ha; Hayden et al. 1985, Robbins et al. 1989a). The two state forests we surveyed (i.e., Morgan Monroe and Yellowwood state forests) represent $>19,000$ ha of mature forest habitat in southern Indiana (Kalb and Mycroft 2013). Although these two state forests are subject to active forest management, Worm-eating Warbler is known to be resilient to low levels of even- and uneven-aged forest management occurring on the landscape (Gram et al. 2003, Wallendorf et al. 2007, Kellner et al. 2016). In addition, Worm-eating Warbler can actually benefit from anthropogenic forest openings during the postfledging period within the context of a forest-dominated habitat matrix (e.g., clearcuts; Vitz and Rodewald 2006, Burke et al. 2017, Ruhl et al. 2018). Given the availability of contiguous mature forest habitat within the Morgan Monroe and Yellowwood state forests, and the known compatibility of Worm-eating Warbler with low levels of active forest management on the landscape, our study highlights the potential importance of terrain features for Wormeating Warbler breeding and nesting success in the southern Indiana portion of the breeding range. However, we cannot make strong forest management recommendations based solely on our results without further scientific investigation.

Management efforts for Worm-eating Warbler often focus heavily on the importance of vegetative, as opposed to terrain, characteristics (Vitz et al. 2013, but see Gale et al. 1997), which is understandable given the pressing threat of habitat fragmentation throughout the breeding range. However, based on our results from analysis at two ecologically relevant scales, we present evidence that terrain variables such as slope and aspect are also correlated with Worm-eating Warbler breeding habitat use within the Yellowwood and Morgan-Monroe state forests of southern Indiana. More research is needed to fully understand the ecological implications associated with the perceived differences between Worm-eating Warbler utilization of NE- and SW-facing slopes, but based on our results, we suggest that private landowners and forestry companies in the southern Indiana region of the breeding range consider the importance of steep SW-facing slopes when designating habitat for conservation purposes.

Responses to this article can be read online at: http://www.ace-eco.org/issues/responses.php/1185

\begin{abstract}
Acknowledgments:
Andy Meier, Patrick Ma, and Charlotte Owings helped coordinate this study. We thank the many technicians who contributed to data collection, and specifically recognize J. Suich, W. Homoya, W. Britton, C. Delancey, and G. MacDonald for their nest-searching efforts. This paper is a contribution of the Hardwood Ecosystem Experiment, a partnership of the Indiana Department of Natural Resources, Purdue University, Ball State University, Indiana State University, and Drake University. Funding for the project was provided by the Indiana Division of Forestry, and the Department of Forestry and Natural Resources at Purdue University. We thank the Amos Butler Audubon Society, Indianapolis, Indiana, for providing a grant to fund field support. Point count, territory mapping, and nest searching studies were conducted in compliance with Federal Banding Permit \#21781 and Purdue Animal Care and Use Committee guidelines (protocol \#110000078C002). Research was conducted in accordance with the code of ethics as prescribed by The Wildlife Society.
\end{abstract}

\section{LITERATURE CITED}

Amundson, C. L., J. A. Royle, and C. M. Handel. 2014. A hierarchical model combining distance sampling and time removal to estimate detection probability during avian point counts. Auk 131:476-494. http://dx.doi.org/10.1642/AUK-14-11.1

Bakermans, M. H., A. D. Rodewald, and A. C. Vitz. 2012. Influence of forest structure on density and nest success of mature forest birds in managed landscapes. Journal of Wildlife Management 76:1225-1234. http://dx.doi.org/10.1002/jwmg.349

Barker, R. J., M. R. Schofield, W. A. Link, and J. R. Sauer. 2017. On the reliability of $\mathrm{N}$-mixture models for count data. Biometrics http://dx.doi.org/10.1111/biom.12734

Barnes, K. W., K. Islam, and S. A. Auer. 2016. Integrating LIDAR-derived canopy structure into Cerulean Warbler habitat models. Journal of Wildlife Management 80:101-116. http://dx. doi.org/10.1002/jwmg.995

Beers, T. W., P. E. Dress, and L. C. Wensel. 1966. Notes and observations: aspect transformation in site productivity research. Journal of Forestry 64:691-692.

Bender, D. J., T. A. Contreras, and L. Fahrig. 1998. Habitat loss and population decline: a meta-analysis of the patch size effect. Ecology 79:517-533. http://dx.doi.org/10.1890/0012-9658(1998) 079[0517:HLAPDA]2.0.CO;2 
Brock, K. J. 2006. Brock's birds of Indiana. Compact disk. Amos Butler Audubon Society, Indianapolis, Indiana, USA.

Brooks, S., and A. Gelman. 1998. Some issues for monitoring convergence of iterative simulations. Computing Science and Statistics 30-36. [online] URL: http://www.stat.columbia.edu/ gelman/research/published/proceedings4.pdf

Burke, A. D., F. R. Thompson, III, and J. Faaborg. 2017. Variation in early-successional habitat use among independent juvenile forest breeding birds. Wilson Journal of Ornithology 129:235-246. http://dx.doi.org/10.1676/15-055.1

Castrale, J. S., E. M. Hopkins, and C. E. Keller. 1998. Atlas of breeding birds of Indiana. Indiana Department of Natural Resources, Indianapolis, Indiana, USA.

Conway, C. J., and T. E. Martin. 2000. Evolution of passerine incubation behavior: influence of food, temperature, and nest predation. Evolution 54:670-685. http://dx.doi.org/10.1111/ j.0014-3820.2000.tb00068.x

Crosby, J. S., and R. M. Loomis. 1974. Some forest floor fuelbed characteristics of black oak stands in Southeast Missouri. Research Note NC-162. U.S. Department of Agriculture, Forest Service, North Central Forest Experiment Station, St. Paul, Minnesota, USA. [online] URL: https://www.nrs.fs.fed.us/pubs/rn/rn_nc162. pdf

Donovan, T. M., and C. H. Flather. 2002. Relationships among North American songbird trends, habitat fragmentation, and landscape occupancy. Ecological Applications 12:364-374. http:// dx.doi.org/10.2307/3060948

Farnsworth, G. L., J. D. Nichols, J. R. Sauer, S. G. Fancy, K. H. Pollock, S. A. Shriner, and T. R. Simons. 2005. Statistical approaches to the analysis of point count data: a little extra information can go a long way. Pages 736-743 in C. J. Ralph and T. D. Rich, editors. Bird conservation implementation and integration in the Americas: proceedings of the third international partners in flight conference. General technical report PSW GTR-191. USDA Forest Service Pacific Southwest Research Station, Asilomar, California, USA. [online] URL: https://www. fs.fed.us/psw/publications/documents/psw_gtr191/

psw_gtr191_0736-0743_farnsworth.pdf

Farnsworth, G. L., K. H. Pollock, J. D. Nichols, T. R. Simons, J. E. Hines, and J. R. Sauer. 2002. A removal model for estimating detection probabilities from point-count surveys. Auk 119:414-425. http://dx.doi.org/10.1642/0004-8038(2002)119[0414: ARMFED]2.0.CO;2

Gale, G. A., L. A. Hanners, and S. R. Patton. 1997. Reproductive success of Worm-eating Warblers in a forest landscape. Conservation Biology 11:246-250. http://dx.doi.org/10.1046/ j.1523-1739.1997.95141.x

Gram, W. K., P. A. Porneluzi, R. L. Clawson, J. Faaborg, and S. C. Richter. 2003. Effects of experimental forest management on density and nesting success of bird species in Missouri Ozark forests. Conservation Biology 17:1324-1337. http://dx.doi. org/10.1046/j.1523-1739.2003.02171.x

Greenberg, R. 1987. Seasonal foraging specialization in the Worm-eating Warbler. Condor 89:158-168. http://dx.doi. org/10.2307/1368770
Hayden, T. J., J. Faaborg, and R. L. Clawson. 1985. Estimates of minimum area requirements for Missouri forest birds. Transactions of the Missouri Academy of Science 19:11-22.

Hijmans, R. J., J. van Etten, J. Cheng, M. Mattiuzzi, M. Sumner, J. A. Greenberg, O. P. Lamigueiro, A. Bevan, E. B. Racine, A. Shortridge, and A. Ghosh. 2017. Package 'raster': geographic data analysis and modeling. $\mathrm{R}$ package version 2.6-7. The $\mathrm{R}$ Foundation, Vienna, Austria. [online] URL: https://cran.rproject.org/web/packages/raster

Howell, C. A., S. C. Latta, T. M. Donovan, P. A. Porneluzi, G. R. Parks, and J. Faaborg. 2000. Landscape effects mediate breeding bird abundance in midwestern forests. Landscape Ecology 15:547-562. http://dx.doi.org/10.1023/A:1008190029786

Kalb, R. A., and C. Mycroft. 2013. The hardwood ecosystem experiment: goals, design, and implementation. Pages 36-59 in R. K. Swihart, M. R. Saunders, R. A. Kalb, G. S. Haulton, and C. H. Michler, editors. The hardwood ecosystem experiment: a framework for studying responses to forest management. General Technical Report NRS-P-108. USDA Forest Service, Northern Research Station, Newtown Square, Pennsylvania, USA. [online] URL: https://www.nrs.fs.fed.us/pubs/gtr/gtr-nrs-

p-108papers/04kalb_mycroft_hee_p108.pdf

Keller, G. S., and R. H. Yahner. 2007. Seasonal forest-patch use by birds in fragmented landscapes of south-central Pennsylvania. Wilson Journal of Ornithology 119:410-418. http://dx.doi. org/10.1676/04-034.1

Kellner, K. F. 2015. jagsUI: a wrapper around rjags to streamline JAGS analyses. $\mathrm{R}$ package version 1.4.1. The $\mathrm{R}$ Foundation, Vienna, Austria. [online] URL: https://CRAN.R-project.org/ package $=$ jagsUI

Kellner, K. F., P. J. Ruhl, J. B. Dunning, Jr., J. K. Riegel, and R. K. Swihart. 2016. Multi-scale responses of breeding birds to experimental forest management in Indiana, USA. Forest Ecology and Management 382:64-75. http://dx.doi.org/10.1016/j.

foreco.2016.10.008

King, D. I., R. M. Degraaf, M.-L. Smith, and J. P. Buonaccorsi. 2006. Habitat selection and habitat-specific survival of fledgling Ovenbirds (Seiurus aurocapilla). Journal of Zoology 269:414-421. http://dx.doi.org/10.1111/j.1469-7998.2006.00158.x

Kreye, J. K., J. M. Varner, J. K. Hiers, and J. Mola. 2013. Toward a mechanism for eastern North American forest mesophication: differential litter drying across 17 species. Ecological Applications 23:1976-1986. http://dx.doi.org/10.1890/13-0503.1

Levin, S. A. 1992. The problem of pattern and scale in ecology: the Robert H. MacArthur award lecture. Ecology 73:1943-1967. http://dx.doi.org/10.2307/1941447

MacArthur, R. H., and J. W. MacArthur. 1961. On bird species diversity. Ecology 42:594-598. http://dx.doi.org/10.2307/1932254

Matsuoka, S. M., C. L. Mahon, C. M. Handel, P. Sólymos, E. M. Bayne, P. C. Fontaine, and C. J. Ralph. 2014. Reviving common standards in point-count surveys for broad inference across studies. Condor 116:599-608. http://dx.doi.org/10.1650/

CONDOR-14-108.1 
Olivero, A. M., and D. M. Hix. 1998. Influence of aspect and stand age on ground flora of southeastern Ohio forest ecosystems. Plant Ecology 139:177-187. http://dx.doi.org/10.1023/A:1009758501201

Peterson, S. M., H. M. Streby, J. A. Lehman, G. R. Kramer, A. C. Fish, and D. E. Andersen. 2015. High-tech or field techs: radiotelemetry is a cost-effective method for reducing bias in songbird nest searching. Condor 117:386-395. http://dx.doi.org/10.1650/ CONDOR-14-124.1

Plummer, M. 2003. JAGS: a program for analysis of Bayesian graphical models using Gibbs sampling. Pages 1-8 in Proceedings of the 3rd international workshop on distributed statistical computing. Technische Universit at Wien, Wien, Austria. [online] URL: http://citeseerx.ist.psu.edu/viewdoc/download? doi=10.1.1.13.3406\&rep=rep1\&type $=$ pdf

Ralph, C. J., S. Droege, and J. R. Sauer. 1995. Managing and monitoring birds using point counts: standards and applications. Pages 161-168 in C. J. Ralph, J. R. Sauer, and S. Droege, editors. Monitoring bird populations by point counts. General Technical Report PSW-GTR-149. U.S. Department of Agriculture, Forest Service, Pacific Southwest Research Station, Albany, California, USA. [online] URL: https://www.fs.fed.us/psw/publications/ documents/gtr-149/pg161_168.pdf

Rasband, W. S.1997-2016. ImageJ. U. S. National Institutes of Health, Bethesda, Maryland, USA. [online] URL: https://imagej. nih.gov/ij/

R Development Core Team. 2016. R: a language and environment for statistical computing. Version 3.2.5. R Foundation for Statistical Computing, Vienna, Austria.

Robbins, C. S., D. K. Dawson, and B. A. Dowell. 1989a. Habitat area requirements of breeding forest birds of the Middle Atlantic States. Wildlife Monographs 103:1-34.

Robbins, C. S., J. R. Sauer, R. S. Greenberg, and S. Droege. $1989 b$. Population declines in North American birds that migrate to the Neotropics. Proceedings of the National Academy of Sciences 86:7658-7662. [online] URL: http://www.pnas.org/content/ pnas/86/19/7658.full.pdf

Robinson, S. K., F. R. Thompson, III, T. M. Donovan, D. R. Whitehead, and J. Faaborg. 1995. Regional forest fragmentation and the nesting success of migratory birds. Science 267:1987-1990 http://dx.doi.org/10.1126/science.267.5206.1987

Rodewald, P. G., and K. G. Smith. 1998. Short-term effects of understory and overstory management on breeding birds in Arkansas oak-hickory forests. Journal of Wildlife Management 62:1411-1417. http://dx.doi.org/10.2307/3802007

Rosenberg, K. V., J. A. Kennedy, R. Dettmers, R. P. Ford, D. Reynolds, J. D. Alexander, C. J. Beardmore, P. J. Blancher, R. E. Bogart, G. S. Butcher, A. F. Camfield, A. Couturier, D. W. Demarest, W. E. Easton, J. J. Giocomo, R. H. Keller, A. E. Mini, A. O. Panjabi, D. N. Pashley, T. D. Rich, J. M. Ruth, H. Stabins, J. Stanton, and T. Will. 2016. Partners in flight landbird conservation plan: 2016 revision for Canada and Continental United States. Partners in Flight Science Committee, Washington, D.C., USA. [online] URL: http://www.partnersinflight.org/wpcontent/uploads/2016/08/pif-continental-plan-final-spread-single. pdf
Ruhl, P. J., C. D. Delancey, and J. B. Dunning, Jr. 2018. Roost preference, postfledging habitat use, and breeding phenology of adult female Worm-eating Warblers (Helmitheros vermivorum) on the breeding grounds. Wilson Journal of Ornithology, in press.

Sauer, J. R., D. K. Niven, J. E. Hines, D. J. Ziolkowski, Jr., K. L. Pardieck, J. E. Fallon, and W. A. Link. 2017. The North American breeding bird survey: results and analysis 1966-2015. Version 2.07.2017. USGS Patuxent Wildlife Research Center, Laurel, Maryland, USA. [online] URL: https://www.mbr-pwrc.usgs.gov/ bbs/

Saunders, M. R., and J. E. Arseneault. 2013. Pre-treatment analysis of woody vegetation composition and structure on the hardwood ecosystem experiment research units. Pages 96-125 in R. K. Swihart, M. R. Saunders, R. A. Kalb, G. S. Haulton, and C. H. Michler, editors. The hardwood ecosystem experiment: a framework for studying responses to forest management. General Technical Report NRS-P 108. USDA Forest Service Northern Research Station, Newtown Square, Pennsylvania, USA. [online] URL: https://www.nrs.fs.fed.us/pubs/gtr/gtr-nrs-

p-108papers/08saunders_arseneault_hee_p108.pdf

Schwilk, D. W., and A. C. Caprio. 2011. Scaling from leaf traits to fire behaviour: community composition predicts fire severity in a temperate forest: leaf length and fire behaviour. Journal of Ecology 99:970-980. http://dx.doi.org/10.1111/j.1365-2745.2011.01828. $\mathrm{x}$

Smith, K. M., W. S. Keeton, T. M. Donovan, and B. Mitchell. 2008. Stand-level forest structure and avian habitat: scale dependencies in predicting occurrence in a heterogeneous forest. Forest Science 54:36-46.

Streby, H. M., and D. E. Andersen. 2011. Seasonal productivity in a population of migratory songbirds: why nest data are not enough. Ecosphere 2:1-15. http://dx.doi.org/10.1890/ES10-00187.1

Turner, M. G., R. H. Gardner, and R. V. O'neill. 2001. Landscape ecology in theory and practice: pattern and process. Springer, New York, New York, USA.

U.S. Fish and Wildlife Service (USFWS). 2008. Birds of conservation concern 2008. United States Department of Interior, Fish and Wildlife Service, Division of Migratory Bird Management, Arlington, Virginia, USA. [online] URL: https:// www.fws.gov/migratorybirds/pdf/grants/BirdsofConservationConcern2008.pdf

Van Horne, B. 1983. Density as a misleading indicator of habitat quality. Journal of Wildlife Management 47:893-901. http://dx. doi.org/10.2307/3808148

Vitz, A. C., L. A. Hanners, and S. R. Patton. 2013. Worm-eating Warbler (Helmitheros vermivorum). Number 367 in A. Poole, editor. The birds of North America. Cornell Laboratory of Ornithology, Ithaca, New York, USA.

Vitz, A. C., and A. D. Rodewald. 2006. Can regenerating clearcuts benefit mature-forest songbirds? An examination of postbreeding ecology. Biological Conservation 127:477-486. http://dx. doi.org/10.1016/j.biocon.2005.09.011

Vitz, A. C., and A. D. Rodewald. 2011. Influence of condition and habitat use on survival of post-fledging songbirds. Condor 113:400-411. http://dx.doi.org/10.1525/cond.2011.100023 
Wallendorf, M. J., P. A. Porneluzi, W. K. Gram, R. L. Clawson, and J. Faaborg. 2007. Bird response to clear cutting in Missouri Ozark Forests. Journal of Wildlife Management 71:1899-1905. http://dx.doi.org/10.2193/2006-386

Watts, B. D., and M. D. Wilson. 2005. The use of pine plantations by Worm-eating Warblers in coastal North Carolina. Southeastern Naturalist 4:177-187. http://dx.doi.org/10.1656/1528-7092 (2005)004[0177:TUOPPB]2.0.CO;2

Wenny, D. G., R. L. Clawson, J. Faaborg, and S. L. Sheriff. 1993. Population density, habitat selection and minimum area requirements of three forest-interior warblers in Central Missouri. Condor 95:968-979. http://dx.doi.org/10.2307/1369432 
Appendix 1. Table A1.1.

\begin{tabular}{llll}
\hline \hline Parameter & Estimate & SD & $P$-value \\
\hline Intercept & -0.35 & 0.07 & $<0.01$ \\
Site SD & 0.01 & 0.09 & - \\
Point SD & 0.00 & 0.00 & - \\
Canopy Height & 0.06 & 0.07 & 0.37 \\
Understory Density & 0.05 & 0.07 & 0.46 \\
Elevation & 0.11 & 0.08 & 0.18 \\
Slope & 0.17 & 0.08 & $0.03^{*}$ \\
Aspect & -0.15 & 0.08 & 0.07 \\
\hline
\end{tabular}

